\title{
Effects of accelerated degradation on metal supported thin film-based solid oxide fuel cell
}

Reolon, R. P.; Sanna, S.; Xu, Yu; Lee, I.; Bergmann, C. P. ; Pryds, N.; Esposito, V.

Published in:

Journal of Materials Chemistry A

Link to article, DOI:

10.1039/C7TA11091J

Publication date:

2018

Document Version

Peer reviewed version

Link back to DTU Orbit

Citation (APA):

Reolon, R. P., Sanna, S., Xu, Y., Lee, I., Bergmann, C. P., Pryds, N., \& Esposito, V. (2018). Effects of accelerated degradation on metal supported thin film-based solid oxide fuel cell. Journal of Materials Chemistry $A, 6(17), 7887-7896$. https://doi.org/10.1039/C7TA11091J

\section{General rights}

Copyright and moral rights for the publications made accessible in the public portal are retained by the authors and/or other copyright owners and it is a condition of accessing publications that users recognise and abide by the legal requirements associated with these rights.

- Users may download and print one copy of any publication from the public portal for the purpose of private study or research.

- You may not further distribute the material or use it for any profit-making activity or commercial gain

- You may freely distribute the URL identifying the publication in the public portal 


\section{Journal of \\ Materials Chemistry A}

\section{Accepted Manuscript}

This article can be cited before page numbers have been issued, to do this please use: R. P. Reolon, S. Sanna, Y. Xu, I. Lee, C. P. Bergmann, N. Pryds and V. Esposito, J. Mater. Chem. A, 2018, DOI:

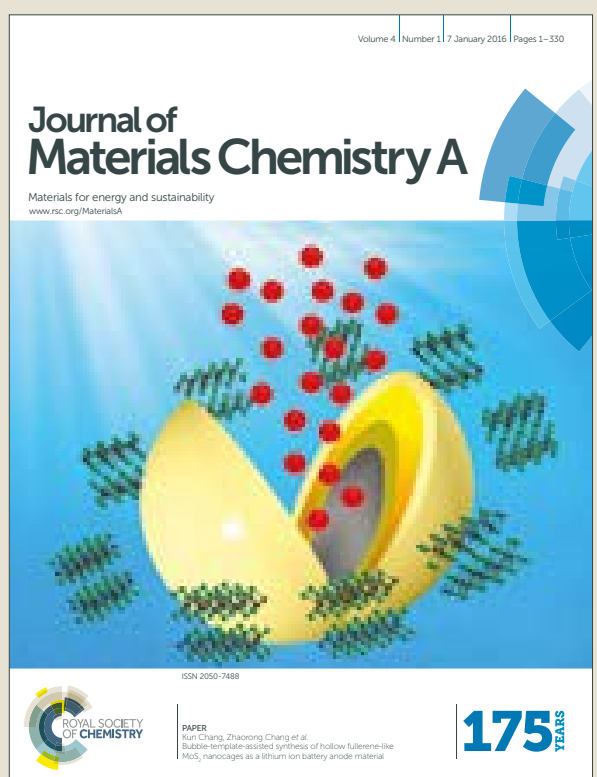

This is an Accepted Manuscript, which has been through the Royal Society of Chemistry peer review process and has been accepted for publication.

Accepted Manuscripts are published online shortly after acceptance, before technical editing, formatting and proof reading. Using this free service, authors can make their results available to the community, in citable form, before we publish the edited article. We will replace this Accepted Manuscript with the edited and formatted Advance Article as soon as it is available.

You can find more information about Accepted Manuscripts in the author guidelines.

Please note that technical editing may introduce minor changes to the text and/or graphics, which may alter content. The journal's standard Terms \& Conditions and the ethical guidelines, outlined in our author and reviewer resource centre, still apply. In no event shall the Royal Society of Chemistry be held responsible for any errors or omissions in this Accepted Manuscript or any consequences arising from the use of any information it contains. 


\section{Journal of \\ Materials Chemistry A}

\section{Effects of accelerated degradation on metal supported thin film- based solid oxide fuel cell}

Received 19th December 2017, Accepted 00th January 2017

DOI: $10.1039 / \times 0 \times x 00000 x$

www.rsc.org/

\author{
R. P. Reolon ${ }^{a}$ b, d, S. Sanna ${ }^{a}$, Y. Xu ${ }^{a}$, I. Lee ${ }^{c}$, C. P. Bergmann ${ }^{b}$, N. Pryds ${ }^{a}$, V. Esposito ${ }^{a}$
}

A thin film-based solid oxide fuel cell is deposited on a Ni-based metal porous support by pulsed laser deposition with a multi-scale-graded microstructure design. The fuel cell, around $1 \mu \mathrm{m}$ in thickness, is composed of stabilizedzirconia/doped-ceria bi-layered dense electrolyte and nanostructured Ni-stabilized zirconia and $\mathrm{La}_{0.6} \mathrm{Sr}_{0.4} \mathrm{CoO}_{3}$ electrodes, i.e. anode and cathodes, respectively. The cell is tested at intermediate temperatures $\left(600-650{ }^{\circ} \mathrm{C}\right)$ with the aim to discern the degradation mechanisms occurring in the cell under accelerated conditions. At open circuit, electrochemical performances are steady, indicating stability of the cell. Under electric load, a progressive degradation is activated. Posttest analysis reveals both mechanical and chemical degradation of the cell. Cracks and delamination of the thin films promote a significant nickel diffusion and new phase formation. Signs of elemental distribution at low temperature are detected throughout the cell, indicating a combination of low energy surface elemental interdiffusion and electromigrative effects.

\section{Introduction}

Developed for use as power sources for mobile devices and for battery replacement in miniaturized systems, thin film based solid oxide fuel cells (TF-SOFCs) can yield high power density above $500 \mathrm{~mW} \cdot \mathrm{cm}^{-2}$ at low temperatures around $400-600{ }^{\circ} \mathrm{C}^{1-}$ 3. As the key for advancing this technology, advanced functional materials are tailored and combined at the nanoscale as thin layers and nanostructures to obtain a high electrochemical conversion at low temperatures ${ }^{4-7}$; The advantages of thin films are to reduce the ohmic resistance at the electrolyte, reduce polarization and blocking effects at the electrodes and at the electrode/ electrolyte interfaces ${ }^{2}$. Reducing the operative temperature below $600{ }^{\circ} \mathrm{C}$ is expected to improve long-term stability and reduced start-up time ${ }^{8-10}$. For the stability, the physics-chemical properties of the materials at the components are crucial $^{11}$. Undesired elemental diffusion and de-mixing impair the electrical performances of the electrolyte ${ }^{12}$, while microstructural changes can reduce the electrochemical activity of the electrodes. These effects exists in SOFCs at high temperatures above $800{ }^{\circ} \mathrm{C} 13,14$. However, they can also occur at low

\footnotetext{
a. Department of Energy Conversion and Storage, Technical University of Denmark (Ris $\varnothing$ campus), Frederiksborgvej 399, 4000 Roskilde, Denmark.

b. Laboratory of Ceramic Materials - LACER. Department of Materials engineering Federal University of Rio Grande do Sul - UFRGS. Av. Osvaldo Aranha, 99, 705 c, Porto Alegre / RS, Brazil.

c. Research Institute of Industrial Science and Technology (RIST), POSCO Global R\&D Center, Songdogwahak-ro, Yeonsu-gu, Incheon, 21985, South Korea d.Correspondence R. Reolon \& V. Esposito: raquelreolon@gmail.com; vies@dtu.dk
}

temperature in TF-SOFCs. In material degradation, temperature mostly controls phase changes, elemental and mass diffusion, leading to detrimental microstructural and chemical transformations. Diffusion mechanisms have very different activation energies among surface, boundaries and the lattice ${ }^{15,16}$. Particularly, bulk interdiffusive effects, such as lattice diffusion, are activated by high activation energy mechanisms and are usually not expected at low-operatingtemperature SOFCs. Nanostructures features are generally "locked" by low temperature processing methods applied as PVD/CVD. These features enhance electrochemical conversion but can be easily "unlocked", undergoing chemical and microstructural degradation ${ }^{17}$ and are generally associated with certain material behaviour, e.g. high diffusivity of certain elements such as $\mathrm{Ni}, \mathrm{Co}$, and Sr. Cell stability can actually be the result of a complex interplay between mechanical and electro-chemical factors. The combination of elemental interdiffusion, electromigration and thermal stress can also involve different components of the cell simultaneously. Critical effects in the support of the cell, such as stress-strain conditions, have been recently discussed for TF-SOFCs ${ }^{18}$ and limitations in increasing the dimension of the FC active area above several squared micrometres while reducing the film thickness in free-standing TF-SOFCs have been also recognized 19. As a result, TF-SOFCs undergo degradation despite the low operating temperatures ${ }^{3}$. On the other hand, the effects of electric current and high energy density on nanoscaled components have been identified as possible factors exacerbating $\mathrm{Ni}$-metal electromigration mechanisms, even at low temperatures ${ }^{20}$. Moreover, high current density in miniaturized components can activate electromigration effects with radical changes in microstructure and chemical 
composition of the materials. Nanomaterials are generally more reactive and more prone to mass diffusion ${ }^{16}$, especially via surface diffusive mechanisms which have low activation energy. This is also considering the short diffusive paths in thin films of a few tens/hundreds of nanometers ${ }^{16,17,21}$ for some key-materials such as cerium oxide and metals, which suffer from chemical expansion and fast diffusion, respectively ${ }^{21}$. Also, although $\mathrm{La}_{0.6} \mathrm{Sr}_{0.4} \mathrm{CoO}_{3}$ (LSC) is known to be a chemically unstable material, not many results are reported on its performance and stability in TF-SOFC.

We present, for the first time, results on accelerated degradation test carried out on metal supported TF-SOFC with a selection of different SOFC materials, i.e. bi-layered CGO/YSZ electrolyte, nanostructured LSC cathode and cubic stabilized YSZ-Ni composite anode. The aim is to highlight the design criteria for TF-SOFCs, especially for those supported on metals. As a case study, we selected the successful "multiarchitecture" configuration, originally proposed for ceramic supported TF-SOFCs ${ }^{22}$, where nanostructures are achieved at the FC through multiple depositions of layers of various thicknesses on a coarse porous support. The cell selected in this work is deposited on a nickel-based porous substrate developed at Antalum/RIST. This configuration has already shown promising results $3,5,22,23$ and metal-supported SOFCs have several advantages in terms of cost, heat management and mechanical reliability ${ }^{24-26}$.

\section{Experimental}

\section{Fabrication of TF-Fuel Cell}

Pulsed layer deposition (PLD) was performed using a KrF laser of $248 \mathrm{~nm}$ wavelength model LPX 200 from Lambda Physik (Germany). As PLD targets, 20 mol\% gadolinium-doped ceria $\mathrm{Ce}_{0.8} \mathrm{Gd}_{0.2} \mathrm{O}_{2-\delta}$ (CGO) sintering at $1450 \circ \mathrm{C}$ for $10 \mathrm{~h}$, and $\mathrm{NiO}(40$ $\%$ vol.)-ScYSZ, 8 mol\% $\mathrm{Sc}_{2} \mathrm{O}_{3}-\mathrm{Y}_{2} \mathrm{O}_{3}-\mathrm{ZrO}_{2}$ (NiO, Sc-YSZ, YSZ, Tosoh) and $\mathrm{La}_{0.6} \mathrm{Sr}_{0.4} \mathrm{CoO}_{3}$ (LSC; EMPA- Switzerland) were fabricated as fully dense pellets by uniaxial pressing and sintered at $1450^{\circ} \mathrm{C}$ for $7 \mathrm{~h}$ in air ${ }^{11,27}$. DOI: $10.1039 / \mathrm{C} 7 \mathrm{TA11091 \textrm {J }}$ As support for the TF SOFC, metallic $\mathrm{Ni}$ foam/Ni-YSZ cermet multilayers were kindly provided by Antalum/RIST. Fig. 1a shows the sequential steps for the TF-SOFC fabrication:

Step 1: Deposition of $\mathrm{NiO} / \mathrm{ScYSZ}$ layer on the metal substrate. The deposition was performed at $100{ }^{\circ} \mathrm{C}$ under vacuum $\left(\mathrm{PO}_{2}=\right.$ $10^{-2} \mathrm{bar}$ ) with $20 \mathrm{~Hz}$ laser pulsed frequency and $290 \mathrm{~mJ}$ energy per pulse for $20 \mathrm{~min}$;

Step 2: A thin dense film of YSZ electrolyte was deposited by $\mathrm{PLD}$, at $600{ }^{\circ} \mathrm{C}$, over $\mathrm{NiO} / \mathrm{ScYSZ}$ layer, under vacuum, $\left(\mathrm{PO}_{2}=10^{-}\right.$ 2 bar) with $20 \mathrm{~Hz}$ laser pulsed frequency and $290 \mathrm{~mJ}$ energy per pulse for $20 \mathrm{~min}$;

Step 3: A thin dense film of CGO was deposited by PLD at 600 ${ }^{\circ} \mathrm{C}$, under vacuum $\left(\mathrm{PO}_{2}=10^{-2}\right.$ bar $)$ with $20 \mathrm{~Hz}$ laser pulsed frequency and $400 \mathrm{~mJ}$ energy per pulse for $20 \mathrm{~min}$;

Step 4: A thin porous film of LSC was deposited by PLD at 100 ${ }^{\circ} \mathrm{C}$ as a cathode layer, under vacuum $\left(\mathrm{PO}_{2}=10^{-2} \mathrm{bar}\right)$ with 20 $\mathrm{Hz}$ laser pulsed frequency and $290 \mathrm{~mJ}$ energy per pulse for 30 $\min$;

Step 5: Platinum film was deposited on cathode side of the cell on top of LSC layer as current collector via sputtering technique at room temperature.

Fig.1 summarizes the experimental procedure, the design architecture of the TF-SOFC and the resulting microstructural features. Chemical, geometrical and microstructural features of the cells, obtained by SEM and EDS characterization, are resumed in table 1 . The final diameter of the active cells was ca. $7 \mathrm{~mm}$.

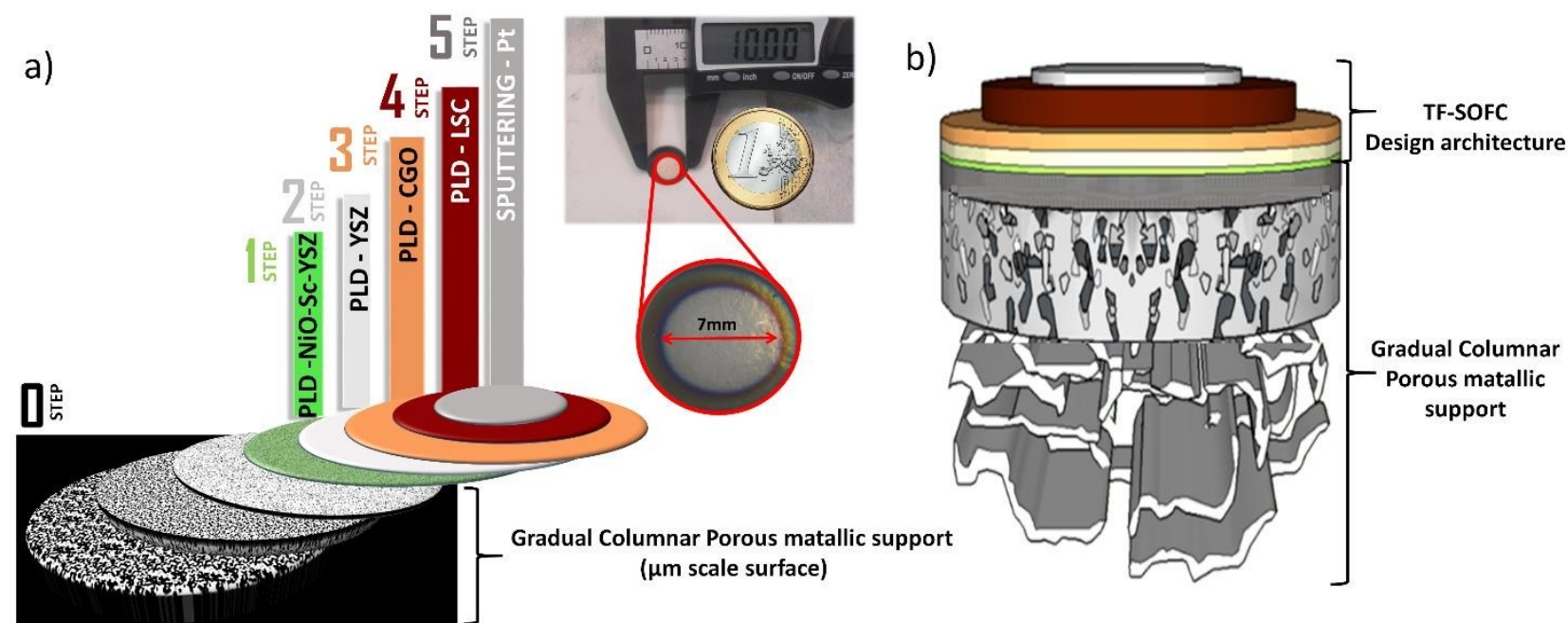

Figure 1.(a) A schematic description showing procedures of making TF-SOFC by PLD with the steps of the layers integration and a photograph of the TF-SOFC; (b) A schematic design of the developed TF-SOFC design architecture. 
Table 1 Composition and function of different layers of the TF-

\begin{tabular}{cccc}
$\begin{array}{c}\text { Layer } \\
\#\end{array}$ & $\begin{array}{c}\text { Composition of major } \\
\text { phases }\end{array}$ & $\begin{array}{c}\text { Thickness } \\
\text { [nm } \pm \text { Std Dev. } \mathrm{nm}]\end{array}$ & Microstructure description \\
\hline $\mathbf{1}$ & $\mathrm{Pt}$ & $1420 \pm 140$ & Porous \\
\hline $\mathbf{2}$ & $\mathrm{La}, \mathrm{Sr}, \mathrm{Co}$ & $240 \pm 15$ & Porous \\
\hline $\mathbf{C}$ & $\mathrm{Ce}, \mathrm{Gd}$ & $560 \pm 54$ & Dense \\
\hline $\mathbf{5}$ & $\mathrm{Y}, \mathrm{Zr}$ & $330 \pm 15$ & Dense \\
\hline $\mathbf{N}$ & $\mathrm{Ni}, \mathrm{Sc}, \mathrm{Y}, \mathrm{Zr}$ & $200 \pm 15$ & Porous \\
\hline
\end{tabular}

\section{Cell test and characterization}

The TF-SOFC was tested at a FUELCON station. The cell was mounted and sealed an alumina house in a furnace. The cell was sandwiched between metal meshes. A nickel mesh on the fuel side and a gold mesh on the oxygen side were used. The furnace temperature was raised to the set testing temperatures of 600 and $650{ }^{\circ} \mathrm{C}$, with a heating rate of 1 ${ }^{\circ} \mathrm{C} / \mathrm{min}$. A mixture of $\mathrm{H}_{2} / \mathrm{N}_{2}\left(6 \% \mathrm{H}_{2}\right.$, volume) was used as a fuel and was supplied to the anode side with a flow rate $0.06 \mathrm{NI} / \mathrm{h}$, while the cathode side was exposed to the synthetic air with a flow rate of $0.06 \mathrm{NI} / \mathrm{h}$. The accelerated degradation test was performed at increasing temperatures from $600{ }^{\circ} \mathrm{C}$ to $650{ }^{\circ} \mathrm{C}$. For I-V data collection the software FuelCon ${ }^{\circledR}$ was used. After each test, the TF-SOFC was characterized by XRD performed on a Bruker D8 Advance diffractometer ( $\mathrm{Cu}$ K $\alpha$ radiation) with $2 \theta$ in the $20-100^{\circ}$ range. The diffraction patterns were compared with standard patterns collected in the ICSD database. The TFSOFC cross-section was prepared by cut the cell, embedding in epoxy and polishing. Scanning Electron Microscopy (SEM) was carried out using a Zeiss Merlin SEM equipped with a field emission gun operated at 5 and $10 \mathrm{kV}$ and Zeiss Supra-35 SEM. For transmission electron microscopy (TEM and STEM), samples of TF-SOFC after accelerated degradation test was prepared in epoxy and then successively thinning with a focused ion beam (FIB) by using a Zeiss Crossbeam 1540xb. Transmission electron microscopy (TEM) was conducted using a JEOL $3000 \mathrm{~F}$ operated with a field emission gun operating at 300kV. Dark-field scanning transmission electron microscopy (DF-STEM) was carried out by using the JEOL 3000F equipped with a STEM unit and a high angle annular dark field (HAADF) detector. The nominal probe size was $0.5 \mathrm{~nm}$ and the camera length was $12 \mathrm{~cm}$. For composition analysis, energy dispersive X-ray spectroscopy (EDS) was carried out by using the equipped Oxford Instruments EDS detector. Bright-field scanning transmission electron microscopy (BF-TEM) images were analysed by using the software Gatan Digital Micrograph while the DF-STEM images as well as EDS element analysis were processed using the software INCA.

\section{Results and discussion}

\section{Pre-degradation test TF-SOFC features and performances}

Microstructural features of the as-deposited TF-SOFC, before testing, are shown in Fig. 2. This shows (a) SEM observations of all the layers and support (no Pt cathode current collector), (b) typical morphology of the PLD layers, (c) a detailed SEM image of the FC layers made by PLD. The individual thicknesses, phase compositions, microstructures and functions of each layer are also summarized in Table 1. Following the "multiarchitectured" concept ${ }^{23}$, the support possessed micrometric grains and porosity, while a NiO-YSZ layer, with of ca. $1 \mu \mathrm{m}$ in thickness, presented smaller features in the range on hundreds in nanometers. This resulted in a dense structure before chemical reduction. The microstructure and size of the anode were further reduced by PLD, depositing the NiO/ScYSZ of a total thickness of ca. $200 \mathrm{~nm}$. The PLD anode layers allowed smoothing down the anode surface roughness from 4 $\mu \mathrm{m}$ at the substrate to few hundreds of nanometres. In the multi-architectures design, smoother and thinner depositions are critical to obtain dense electrolytes, without cracks and pinholes ${ }^{22,28,29}$. The bilayered-electrolyte (CGO/YSZ) used in
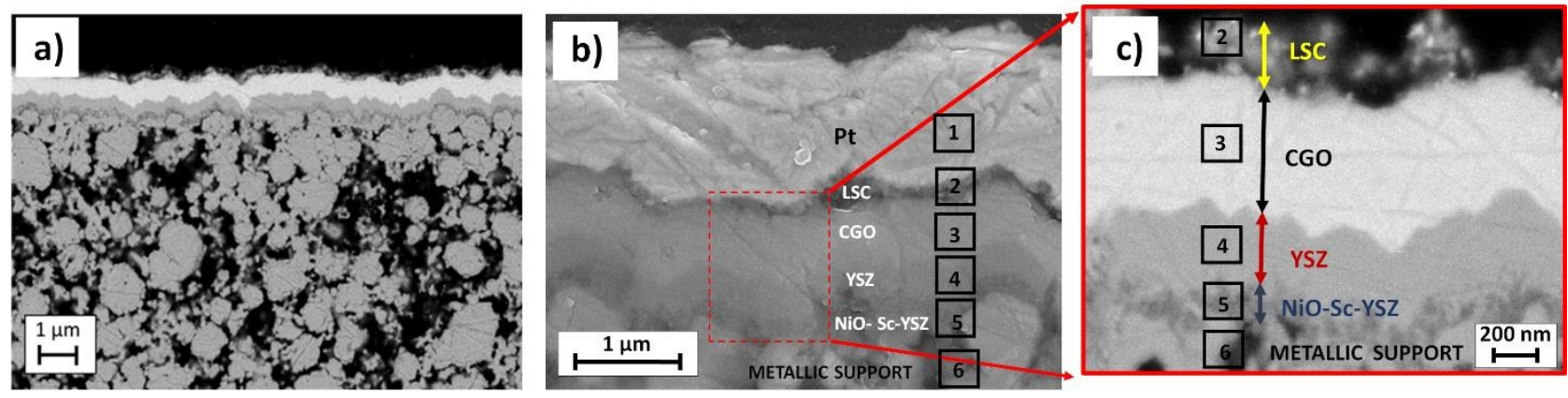

Figure 2 A SEM micrograph showing: a) An overview of all deposited layers for the TF-SOFC developed without Pt current collector. (b) A zoom-in SEM micrograph of the deposited layers. (c) Measuring the thickness of each layer. For the dimensions measure was used the software ImageJ. The numbers indicated in the SEM image indexed the correspond layer listed in the table 1. 
this work showed a good adherence to the substrate, dense and pinhole-free (Figs. $2 \mathrm{~b}$ and $2 \mathrm{c}$ ). The total thickness was ca. $900 \mathrm{~nm}$, i.e. ca. $330 \mathrm{~nm}$ at the YSZ and ca. $560 \mathrm{~nm}$ at the CGO part. The YSZ/CGO is generally adopted in LCS-cathode-based SOFCs. The use of CGO at the cathode side hinders the $\mathrm{Sr}$ segregation towards the YSZ layer and it ensures higher total ionic conductivity ${ }^{30}$. On the other side, the YSZ layer protects the CGO from chemical reduction, avoiding thus mechanical stress and electronic leaks at the electrolyte ${ }^{31}$. Figs. $2 b$ and $2 c$ show the influence of the support roughness at electrolyte morphology in an overall waviness replicating the $\mathrm{Ni}$-metal particles at the support. At the cathode side, LSC cathode and a Pt current collector were deposited by PLD and sputtering, respectively (Fig. 2b). The resulting LSC cathode of $c a .200 \mathrm{~nm}$ was porous and nano-crystalline. The thickness of the $\mathrm{Pt}$ sputtered was around $1.5 \mu \mathrm{m}$. Thick current collector ensures a proper electronic connectivity at the electrode and avoids typical de-wetting effect occurring at metal/ceramic interface ${ }^{32,33}$. In TF-SOFCs, porous nanocrystalline electrodes deposited by PLD, are generally unstable, especially for Ni-YSZ composites. However, a post-annealing step, e.g. $700^{\circ} \mathrm{C}$, has been proved to avoid severe $\mathrm{Ni}$ agglomeration and lack of electronic percolation by promoting densification and crystallinity at the anode of a ceramic-supported TF-SOFC ${ }^{34,35}$.
For metal supported TF-SOFCs, a further thermal treatment cannot be carried out in conditions thatDexidizezthe7sapport and impairing the cell. For the cathode, the LSC layer resulted nanostructures with nano-metric porosity, which is typically obtained at low deposition temperatures ${ }^{36}$. On the other hand, a degradation test, allows clarifying the typical degradation mechanisms occurring at the original nano-crystalline morphology of electrodes.

\section{Accelerated degradation test}

In this work we have carried out degradation tests at 600-650 ${ }^{\circ} \mathrm{C}$, in order to avoid densification, solid solution formation, or phase transformations which are artefacts for this kind of analysis. For the electrical characterization, OCV curves were registered over time while electric loads were applied in potentiometric fashion, where at constant OCV was achieved, by collecting I-V plots and calculating the related power density, $\mathrm{P}$, at the cell. Fig. 3 shows the overall electrochemical behaviour at $600-650{ }^{\circ} \mathrm{C}$, including the open circuit voltage (OCV) vs. time (Fig. 3a) and the I-V-P curves at different stages of the test (Fig. 3b, c, d). At the first stage, Fig. 3a shows that cell reached the equilibrium at $650{ }^{\circ} \mathrm{C}$ with heating rate of $1^{\circ} \mathrm{C} / \mathrm{min}$ after 11 hours of reduction at the anode side.
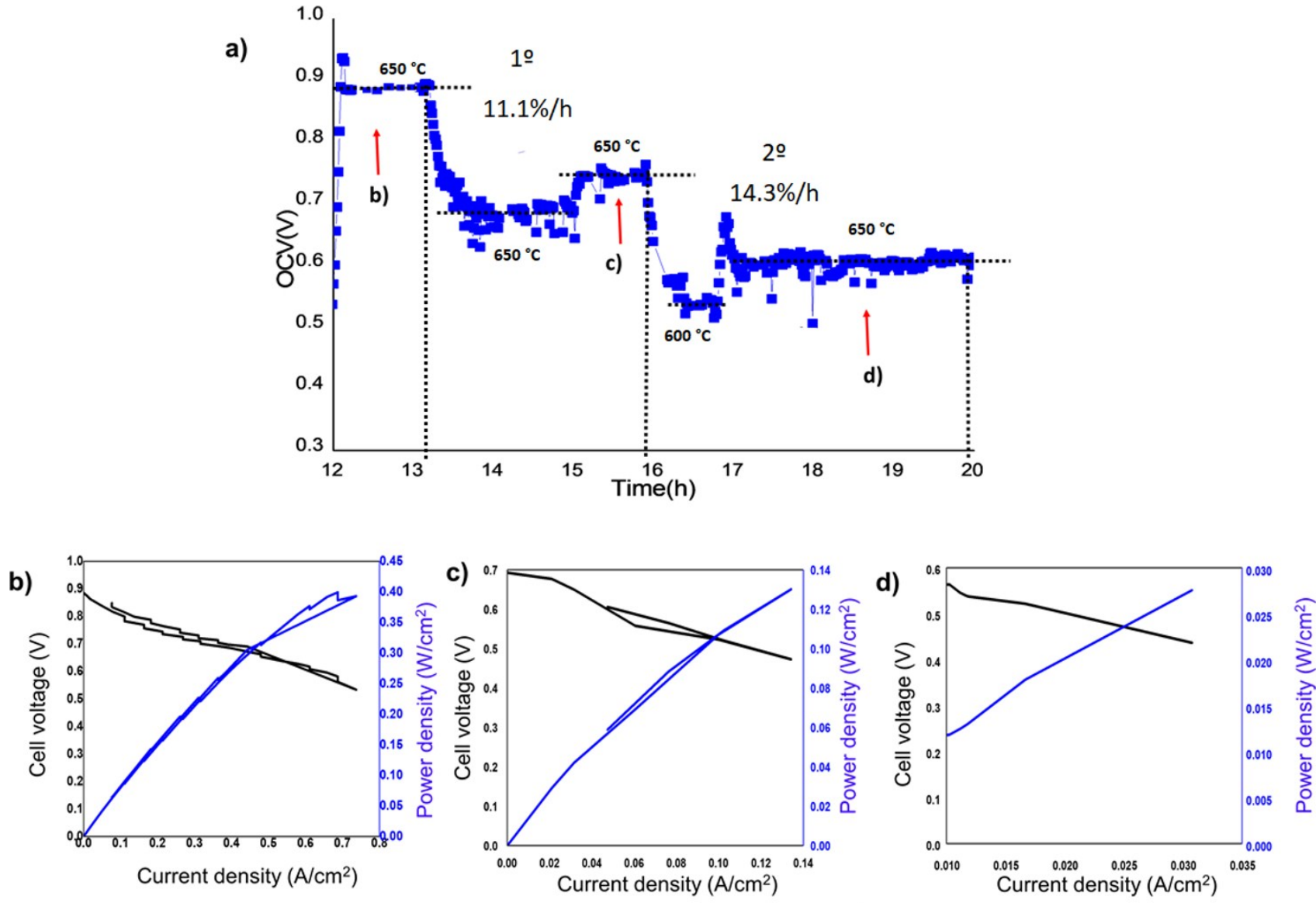

Figure 3 . a) Panel on the performances OCV vs Time during the accelerated degradation test. Graphics IV curves based on the performances of the micro fuel cell during the accelerated degradation test: b) IV curve shows a OCV $0.91 \mathrm{~V}$ and a power conversion of $400 \mathrm{~mW} \mathrm{~cm}^{-2}$ in a mixture of $\mathrm{H}_{2} / \mathrm{N}_{2}\left(8 \% \mathrm{H}_{2}\right.$, volume) as a fuel at $650{ }^{\circ} \mathrm{C}$; c) I-V curve shows a OCV $0.7 \mathrm{~V}$ and a power conversion of $131 \mathrm{~mW} \mathrm{~cm}{ }^{-2}$ in a mixture of $\mathrm{H}_{2} / \mathrm{N}_{2}\left(8 \% \mathrm{H}_{2}\right.$, volume) as a fuel at $6500^{\circ} \mathrm{C}$ after the first degradation. $\mathrm{d}$ ) IV curve shows an OCV $0.55 \mathrm{~V}$ and a power conversion of $27 \mathrm{~mW} \mathrm{~cm}{ }^{-2}$ in a mixture of $\mathrm{H}_{2} / \mathrm{N}_{2}\left(8 \% \mathrm{H}_{2}\right.$, volume $)$ as a fuel at $650{ }^{\circ} \mathrm{C}$ after the second degradation observed. 


\begin{tabular}{ccccc}
\multicolumn{5}{c}{$\begin{array}{l}\text { Table 2. Open Circuit Voltage }(\mathrm{OCV}), \text { Power Density and area specific resistance } \\
\text { (ASR) variation during the accelerated test of the cell }\end{array}$} \\
\hline \begin{tabular}{ccccc}
\hline I-V curve \\
at 650
\end{tabular} & $\begin{array}{c}\text { OCV } \\
(\mathrm{V})\end{array}$ & $\begin{array}{c}\text { Power Density } \\
(\mathrm{mW} \mathrm{cm}-2)\end{array}$ & $\begin{array}{c}\text { ASR } \\
(\Omega \mathrm{cm} 2)\end{array}$ & $\begin{array}{c}\text { Degradation } \\
\text { Stage }\end{array}$ \\
\hline A & 0.91 & 400 & 0.47 & $\begin{array}{c}\text { Without } \\
\text { degradation }\end{array}$ \\
\hline B & 0.70 & 131 & 1.69 & $\begin{array}{c}\text { After 10 } \\
\text { degradation }\end{array}$ \\
\hline C & 0.55 & 27 & 6.50 & $\begin{array}{c}\text { After 20 } \\
\text { Degradation }\end{array}$ \\
\hline
\end{tabular}

The chemical reduction by hydrogen-fuel is the necessary step to obtain metallic $\mathrm{Ni}$ and electronic percolation at the anode. After reduction, the cell showed a constant OCV value of 0.91 $\mathrm{V}$. This is lower than the thermodynamic value of $1.1 \mathrm{~V}$. However, TF-SOFCs often show lower performances than conventional SOFCs, as also reported in literature for porous metallic substrates 28,37 , for cells on nano-porous supports with a single layer of YSZ electrolyte ${ }^{38,39}$ and for bi-layer electrolyte TF-SOFC at low temperature ${ }^{31}$. Low OCV is usually attributed to gas or electronic leaks across the electrolyte. These are due to fissures/pinholes or chemical contamination at the electrolyte which are not significant enough to equalize the electrochemical potential across the electrodes. Presence of defects in thin film electrolyte has larger impact than on thick electrolyte and low OCV values can be a sign of incipient decay of the electrolyte. Although low, the measured OCV was steady and an electric load was then applied though the potentiometric test. Figure $3 \mathrm{~b}$ shows I-V-Power density (P) curves registered at the first stage, as indicated by the arrow in Fig. 3a. For this first measurement, a power density of $400 \mathrm{~mW}$ $\mathrm{cm}^{-2}$ was achieved applying a max current density of $0.7 \mathrm{~A} \cdot \mathrm{cm}^{-2}$ for one charge-discharge cycle. The ASR, calculated from the slope of the first IV curve, was $0.47 \Omega \cdot \mathrm{cm}^{2}$. Such performance are comparable with other TF-SOFC developed reported literature for thin film designs ${ }^{3,5}$. It is also worth noticing that for our sample, low current and diluted $\mathrm{H}_{2} / \mathrm{N}_{2}$ (8\% volume $\mathrm{H}_{2}$ in $\mathrm{N}_{2}$ ) fuel were used, especially to avoid irreversible electrochemical stress at the cell. Therefore, the full potential of the cell was certainly not expressed. Fig. 3a shows that after the test under electric load, the degradation occurred in 2 hours, where the OCV decreased from $0.9 \mathrm{~V}$ to a steady $0.8 \mathrm{~V}$, with a degradation-rate of $c a .10 \% \mathrm{~h}^{-1}$. Fig. 3 c reports the I-V-P curves taken at this stage. At the measurement, the OCV decreased to $0.7 \mathrm{~V}$ and a power density to $c a .130 \mathrm{~mW} \mathrm{~cm}^{-2}$ was measured for a load of $0.13 \mathrm{~A} \mathrm{~cm}^{-2}$. The cell resulted in a total loss of around $67 \%$ with respect of the initial performances and the ASR, calculated from the I-V curve, was $1.69 \Omega \cdot \mathrm{cm}^{2}$. Yet, the potentiometric measurement triggered another loss in OVC. That was recorded for ca. $1 \mathrm{~h}$, where the OCV decreased from $0.7 \mathrm{~V}$ to $0.5 \mathrm{~V}$, with a degradation rate of ca. $14 \% \mathrm{~h}^{-1}$. The OCV was again rather stable until the last potentiometric test was performed (Fig. 3d). At this final stage the cell failed with a highly resistive with power density around
$27 \mathrm{~mW} \mathrm{~cm}^{-2}$ and a total loss of around $80 \%$, while the ASR increased to $6.5 \Omega \cdot \mathrm{cm}^{2}$. Table 2 summarizes 0 the $/$ meastoped values from the I-V-P curves, including the OCV, area specific resistance (ASR) and power density. It is worth noticing that, while the OCV was maintained constant at the different stages of the degradation, the applied electric load in the I-V test triggered the degradation. Such an effect suggests that while the OCV can be maintained in the long term the actual operation can activate degradation. The result is also relevant considering that long term stability TF-SOFC are generally shown in absence of applied electrical loads while IV curves are shown after the long term stability test ${ }^{23}$.About the factors leading to progressive degradation, they resulted related to those leading to low OCV. Gas leak through the electrolyte due to defects at the electrolyte can be listed among them. The strong influence of the current in the activation of degradation also indicates that electronic leak and chemical contamination can occur.

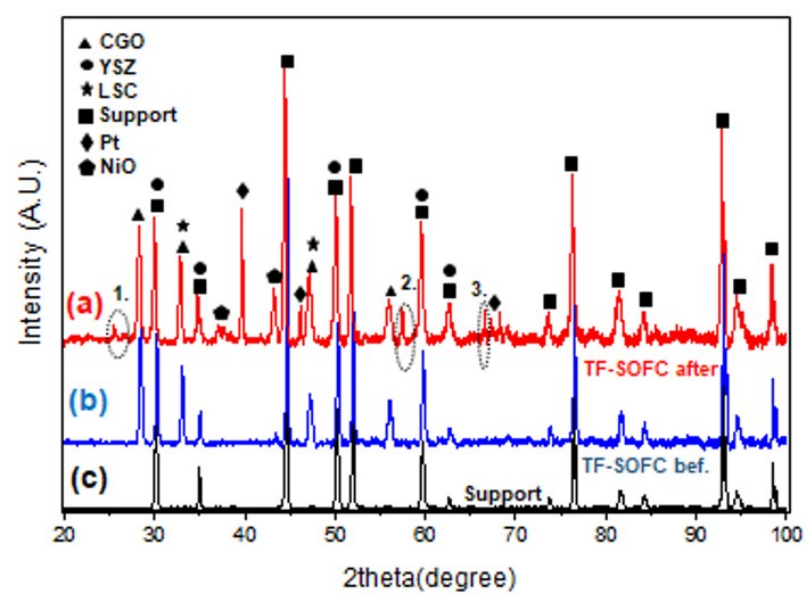

Figure 4 XRD pattern of the TF-SOFC deposited on metallic Ni/Ni-YSZ support film (before and after the accelerated degradation test) and that of pattern of all main composition layers from ICSD standard data base.

\section{Structural, microstructural and chemical characterization}

To clarify whether new phases formed at the materials' interfaces after the test, a XRD analysis on the cells was performed before and after the test. Fig. 4 shows the XRD patterns of TF-SOFC deposited on metallic Ni/Ni-YSZ support film before (a) and (b) after the accelerated degradation test. Fig. 4(c) shows the XRD patterns of the metallic support, for comparison. The analysis showed that, while the pattern before the test corresponded to the expected crystalline phases, the TF-SOFC after the test showed the formation of unidentified extra peaks (dashed circles in Fig. 4). Due to the low temperatures, neither elemental diffusion nor new phase formation was anticipated, while, remarkably, the extraphase/s could be detected by XRD, although this technique has a minimum detection threshold around $8 \%$ vol. of the total crystallinity. Furthermore, presence of $\mathrm{NiO}$ after the test confirmed that the oxidation of the anode materials occurred 
as a possible result an oxygen-Ni reaction due to leakages at the electrolyte. Reduction of the cathode can also occur. Formation of $\mathrm{La}_{2} \mathrm{O}_{3}$, typical of LSC degradation was however not detected by XRD. Effects of degradation mechanisms were observed by TEM/STEM-EDS. At the microstructural level, Fig. 5 shows typical cross section of the cell after test including the full cell components (a) and a detail on the electrolyte (b). Chemical composition at the layer could be recognized by the EDS linear scan overlapped to Fig $5 \mathrm{~b}$. A pronounced change in the morphology of the layers was observed after the cell test with respect of the features before the test, as shown in Fig. 2. At the cathode side, cracks, pores and sharp grains were observed especially at the CGO layer (highlighted red circles in Fig. 5a). At the anode side, the YSZ layer was relatively dense with vertical multiple cracks. Black arrows in Fig. 5a show extremely sharp cracks and apertures at the electrolyte both at the CGO and the YSZ layers. The vertical orientation of the cracks suggest a certain weakness of the microstructure produced by $\mathrm{PLD}^{40}$. As also shown in previous literature, this is generally columnar with aligned vertical grain boundaries ${ }^{41}$. Fig. $5 b$ shows a set of vertical cracks in with better detail. The cracks are in the range of hundreds of nanometers in length and few nanometers in width. Such kind of failure at the electrolyte layer is critical and exposes the cell to gases leak. Cracks may be caused by mechanical stress between the substrate and the electrolyte during the thermal and/or chemical cycles. A not dense electrolyte can either lead to reduction of the cathode side, by fuel cross over, or anode oxidation, by oxygen leak at the anode ${ }^{42}$. However, while the anode layer in general presented depleted but integer, severe degradation at the CGO layer seemed to indicate that leak of hydrogen to the cathodic was prominent in the sample. Fuel leak through the crack can indeed trigger direct combustion of the fuel at the crack with localized rising of the temperature in the so-called hot-spots. As result, severe fracture and formation of a sponge-like cluster with $\mathrm{Ni}-\mathrm{Ce}-\mathrm{Gd}$-based composition were formed. The LSC cathode layer resulted detached from the cells and degraded in several regions. On the other side of the cell, the anode resulted rather homogenous and multi-scale Ni particle could be identified at the cell. Chemical analysis on the cell was carried out by TEM and STEM/EDS. In Fig. 5b, the TEM/EDS line scan indicated a nickel distribution across the cell with a malx tooncentratiba9at the anode layer. However, $\mathrm{Ni}$ was also detected at the YSZ, CGO and at the LSC layers. Ni migration is not expected at temperatures below $650{ }^{\circ} \mathrm{C}$ and suggests the concurrence of chemical and/or electro-migration effects occurring at the nanoscale. Another unexpected effect was the sign of cerium reaction with $\mathrm{Ni}$ at the sponge-like formations as well as to the Ce depletion from the electrolyte toward both the YSZ and the LSC layers. Solid state $\mathrm{CeO}_{2}-\mathrm{ZrO}_{2}$ solutions are generally formed by $\mathrm{Zr}$ migration and it implies high temperature lattice diffusion mechanisms, which are unlikely at the test conditions used in this work. Formation of hot-spots at the electrolyte can trigger elemental diffusion. However, a localized degradation would have been expected in that case, while such solid state reaction seemed to be homogeneously distributed at the layers and no-sensitive raise of the temperatures was registered during the test to justify such a spread elemental intermixing. Moreover, cerium migration toward the LSC layer was also associated with a structural degradation and the sponge-like formations in Fig. 5a. Remarkably, none of those phases could be related to the XRD analysis shown in Fig.4. A detailed chemical investigation at the interfaces was carried out to clarify the nature of these effects.

\section{YSZ/GCO bi-electrolyte interface}

STEM/EDS analysis was performed at the YSZ/CGO interface in several regions, especially to have a better statistics and avoid local-restricted characterization. EDS was done both by line scan analysis and mapping in the different regions of the YSZ/CGO interface. Fig. 6 shows two selected regions: (a) a representative region around the vertical cracks and (b) a representative region on a dense region, with no observable cracks in the surroundings. For the cracked area in Fig. 6a, the line scan revealed presence of nickel and Ce-Zr intermixing at the interface. The line scan results clearly illustrate the elemental distributions as a function of distance from the interface indicated as 0 symbol (Fig. 6a). The penetration length to Ce is around $86 \mathrm{~nm}$ (red arrow) into the YSZ layer and $\mathrm{Zr} 47 \mathrm{~nm}$ (black arrow). This feature describes a certain chemical contamination due to elemental diffusion occurring at $650{ }^{\circ} \mathrm{C}$. For the crack surroundings, interdiffusion can
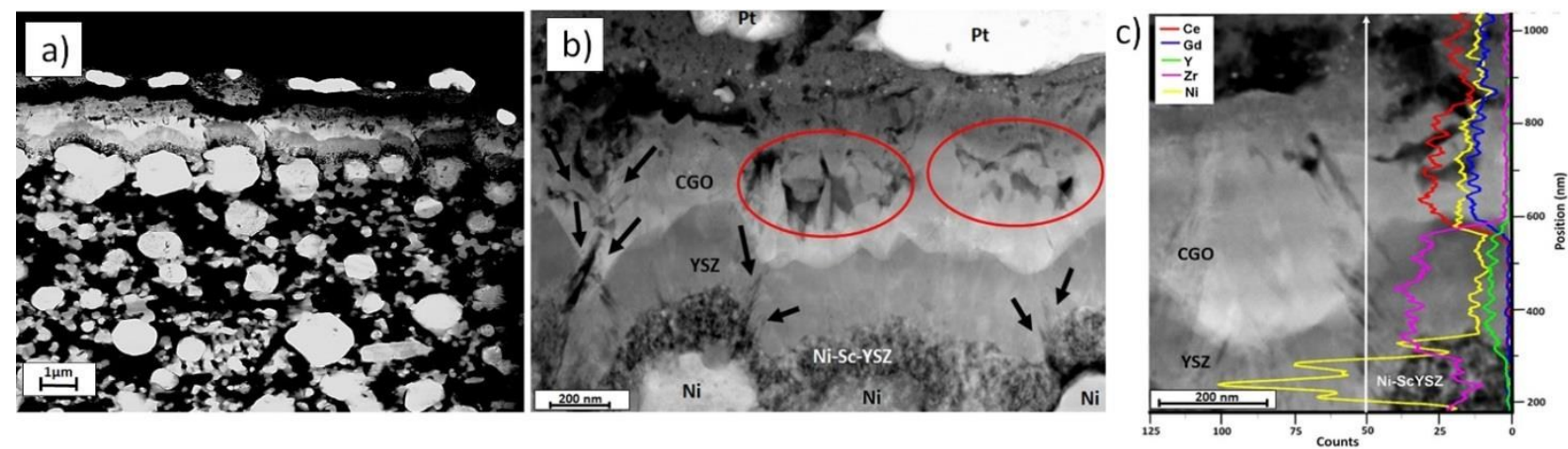

Figure 5 (a) TEM image of overview of the TF-SOFC after test, (b) TEM image zoom-in of the TF-SOFC after test (c). Line scan analysis overview image of the micro fuel cell after operation. For each element was used the respective lines: Ce L, Zr K, Ni K, Y K and Gd L. 


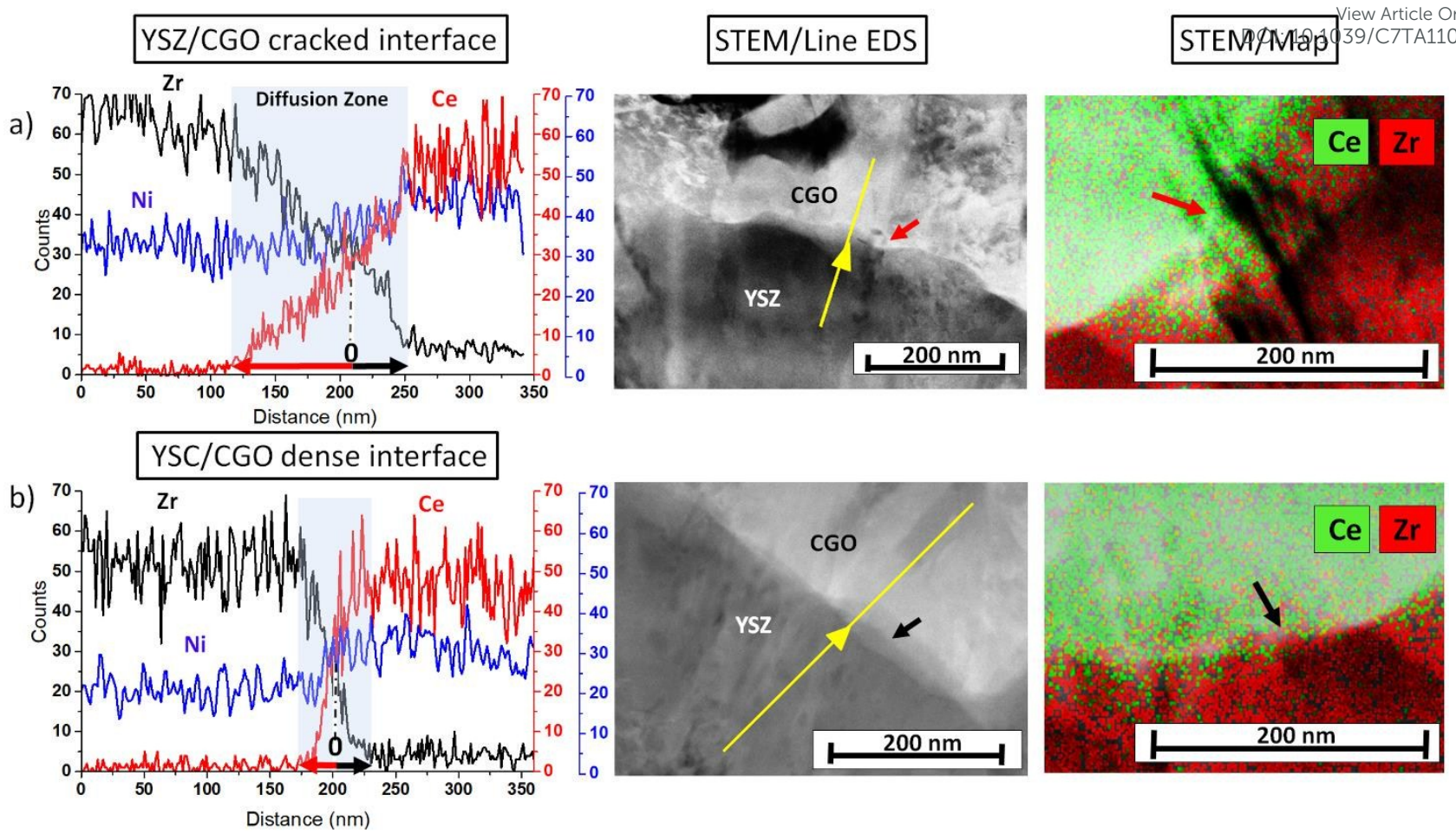

Figure 6 STEM/EDS Line scan and Mapping in the interface between CGO/YSZ. For each element was used the respective lines: Ce L, Zr K and Ni K. (a) Line scan close to the fissure, the intersection region between CGO/YSZ layers was represented by the zero line around $206 \mathrm{~nm}$;(b) Line scan without fissure close; the intersection region between CGO/YSZ layers was represented by the zero line around $200 \mathrm{~nm}$. Regions representation where was evaluated the line scan with/without fissure .Mapping shows the region between CGO/YSZ was presented significative interdiffusion around the cracks and more moderate without cracks. The diffusion can be described for Ce in green colour and $\mathrm{Zr}$ in red colour.

proceed via surface mechanisms that can occur at low temperatures. This is indeed expected for migration of metallic $\mathrm{Ni}$ at the YSZ and CGO surface but is not for NiO and for CeOZrO intermixing. Fig. $6 \mathrm{~b}$ shows different results for the dense areas at the YSZ/CGO interface, indicated as 0 symbol (Fig. 6b). The penetration length to $\mathrm{Ce}$ is around $25 \mathrm{~nm}$ (red arrow) into the YSZ layer and Zr $37 \mathrm{~nm}$ (black arrow). The absence of crack would exclude the surface diffusive path, suggesting either bulk or grain boundary diffusive paths. However, while metallic-Ni migration through columnar grain boundaries is plausible, the $\mathrm{Ce}-\mathrm{Zr}$ solid solution formation is via lattice mechanisms only. For the test condition used in this work the intermixing was found to be of around $200 \mathrm{~nm}$, with a deeper diffusion of $\mathrm{Ce}$ than $\mathrm{Zr}$ after cross the interface. These results, although unexpected at $650^{\circ} \mathrm{C}$, are consistent with some other results indicating a fast interdiffusion of Ce cation into $\mathrm{Zr}$ in reducing conditions can occur via an inversion of the cation diffusion mechanisms ${ }^{43}$. Elemental maps in Fig. 6 in different areas allow visualizing the interdiffusive effects in detail, showing regions of Ce-Zr intermixing at the electrolyte layers. Red arrows in Fig. 6 also highlight the area of diffusion around the cracks, while the black arrows indicate the region without cracks. The mapping in the region close to the cracks shows a high concentration of cerium.

\section{Anode/electrolyte interface}

For the $\mathrm{Ni}$ interdiffusion, the EDS analysis highlighted a spread contamination that started at the Anode/Electrolyte interface and migrated throughout the electrolyte toward the cathode side. This resulting process was likely facilitated by the cracks. Particularly, Fig. 7 shows a detailed STEM image of the anodeelectrolyte interface, including a magnification of the cracked electrolyte with the corresponding line (inside the crack) and map analysis. Fig. 7a reveals a strong depletion of material at the anode layer that resulted in porosity and voids (see red arrow) that were not observable before the test. Elemental analysis in Fig. 7 confirmed $\mathrm{Ni}$ depletion and spreading all around the electrolyte, especially at the cracks for the possible formation of hot-spots. A line scan also revealed a high concentration of $\mathrm{Ni}$, comparable with the $\mathrm{Zr}$ distribution, inside the crack. The elemental map showed presence of $\mathrm{Ni}$ at core of the electrolyte (blue cameo in Fig. 7-map analysis). As a conclusive remark for the analysis carried out at anode/electrolyte interface is that $\mathrm{Ni}$ represents a critical component of the cell. This is known in SOFCs operating at high temperatures, where $\mathrm{Ni}$ coarsening, agglomeration and redox cycle are promoted by high operative temperatures and electrochemical cycling ${ }^{44}$. These are thus critical effects, leading to slow degradation of the performances in bulkSOFCs, which can also affect TF-SOFC at low T, where diffusive paths are in the nanometric range. With respect to the diffusive path, influence of the electro-migration mechanism is 

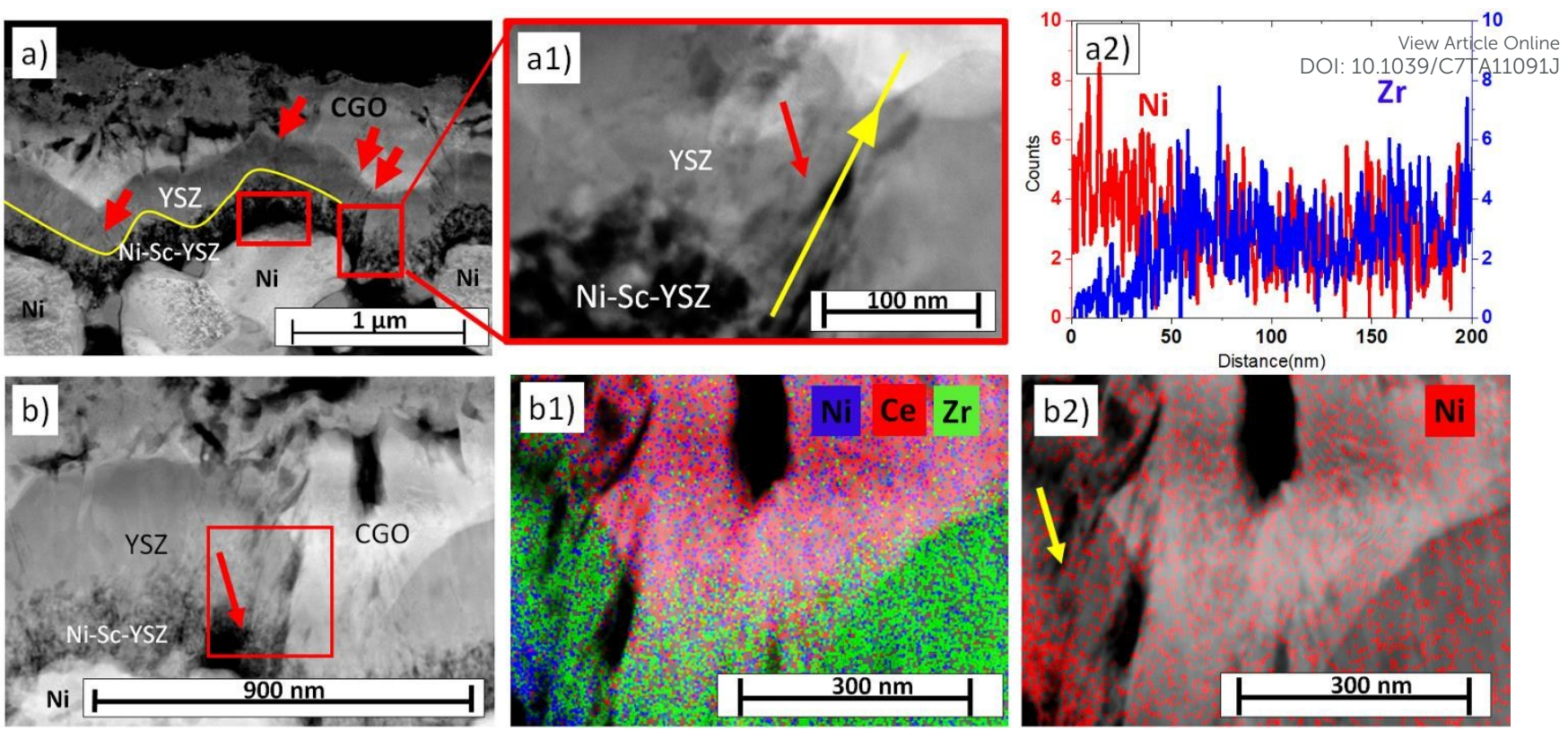

Figure 7 STEM/EDS Line scan and Mapping in the interface between anode and anode interface. For each element was used the respective lines: Ce L, Zr K and Ni K. (a Overview of the anode side for the thin film developed, influence of deposition and development based on the surface of the support,,(waves shapes and fissures) ;(a1) Line scan region analysed through the fissure, from the anode side;( (a2) Line scan through the fissure described for $\mathrm{Ni}$ in red colour and $\mathrm{Zr}$ in red blue from the anode side; ( b) Overview of the anode side for the thin film developed Region representation where was evaluated the mapping analysis, (b1) Mapping shows the region between CGO/YSZ presented significant interdiffusion around the cracks for instance Nickel diffusion (b2) Mapping shows the region between anode support and YSZ with high diffusion of nickel through fissures.

however less clear. Formation of NiO-based compounds by $\mathrm{Ni}$ oxidation can lead to the $\mathrm{Ni}$ migration toward the cathode. Electrochemical effects at the electrodes can also boost $\mathrm{NiO}$ formation. However, due the mostly complex chemistry occurring during degradation and the presence of unknown phases detected at after the test, such electrochemical factors are difficult to be identified.

\section{Cathode/electrolyte interface}

The complexity of the degradation effects at the cell is particularly clear at the cathode/electrolyte interface. Fig. 8 shows STEM/EDS analysis including the CGO, LSC and Pt layers. This appears severely changed by the degradation test, with the presence of mechanical fractures at the CGO layer, formation of new particles, and voids embedded in a thick sponge-like formation. The LSC layer was drastically reduced from the original $200 \mathrm{~nm}$ continuous layer to a few La-Co-Nibased clusters. The Sr dopant in LSC could not be detected by the STM/EDS and punctual phase identification at the clusters was not possible due to inconsistency of the elemental distribution and the reduced size of few tens of nanometres. For the sponge-like formation, Fig. 8 shows several small particles and voids. It was found to be crystalline and based on $\mathrm{Ni}$-La-Ce-Co oxides. Traces of strontium were detected at the cathode side very low and spread (Fig. 8b). Strontium oxide is known to be highly diffusive in oxidative conditions and it can also evaporate when it is reduced to metallic $\mathrm{Sr}$ at the anode side ${ }^{45,46}$. A very low amount of platinum was detected at the cathode, while intermetallic reaction between $\mathrm{Pt}$ and $\mathrm{Ni}$ was revealed by the formation of insulated particles, located beneath the sponge-like formation. A detail of such morphology is shown in Fig. 8c. Presence of nickel was especially observed at the surface of the Pt-based particles (Fig. 8d). Presence of metallic Ni-Pt alloy also indicates a reduction of compound as effect of direct reaction of cathode materials with the hydrogen. Evidences of a direct reaction between the hydrogen and the cathode materials at the electrolyte/cathode interface can be related to the mechanical failure of the $\mathrm{CGO}$ as a possible consequence of the chemical expansion-contraction of this material from reducing condition
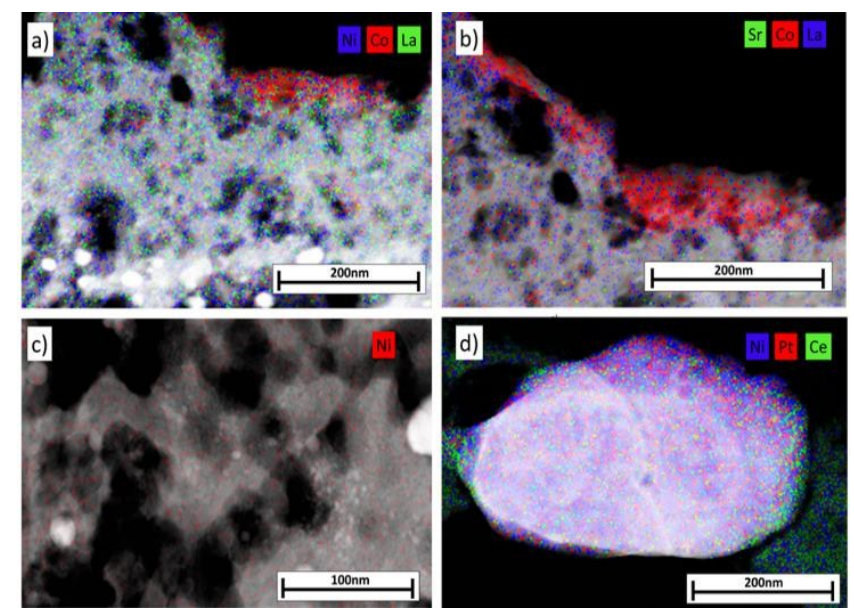

Figure 8 a) Mapping STEM/EDS interface region of LSC/CGO, red colour represents the counts of cobalt, blue represents Nickel and green represents Lanthanum, b) Mapping STEM/EDS interface region of LSC/CGO zoom in. c) Mapping STEM/EDS zoom in the sponge like structure in the CGO layer after the accelerated test. d) STEM/EDS mapping in the platinum particle from current collector deposited by sputtering on top of the LSC cathode layer. When green color represents cerium counts, blue represents nickel and red represents the platinum. 
to oxidative conditions, respectively ${ }^{42}$. However, the dramatic nature of the transformation observed at the cathode side suggests that strong elemental diffusion occurred at the cell during operation, both in the form of oxides and metallic alloys.

\section{Conclusions}

A degradation test on a metal-supported thin-film-based SOFC was carried out at intermediate temperatures of $600-650{ }^{\circ} \mathrm{C}$ and in $8 \% \mathrm{H}_{2}-\mathrm{N}_{2}$ safety gas mixture as fuel. The cell design was selected on some of the best performing materials, usually selected in high performance SOFC, such as YSZ/CGO bi-layer electrolyte, nanostructured $\mathrm{Ni}$-YSZ composite at the anode, and nanostructured $(\mathrm{La}, \mathrm{Sr}) \mathrm{CoO}_{3}$ perovskite as the cathode. The test revealed an intrinsic weakness of the cell related to the reduced size of the thin film components and their microstructural features. Gas leakage through the electrolyte was observed at the cell already at the beginning of the test as a possible effect of a thermomechanical mismatch between the TF-SOFC and the metallic support. Steady OCV conditions could be achieved in the cell, while degradation mechanisms were activated by applying an electric load during potentiostatic measurements. Degradation was observed to occur at a constant rate of ca. 10-15 \% $\mathrm{h}^{-1}$ after the potentiostatic measurements, indicating a contribution of slow but irreversible electromigrative effects in the cell. Microstructural and chemical analyses on the cell after testing revealed a concurrence of mechanical and chemical effects on the cell. Fracturing of the electrolyte with formation of vertical cracks and sharp fractures indicate an intrinsic weakness of the YSZ/CGO electrolyte. The orientation and shape of the fractures were related to the columnar nature of the YSZ/CGO thin films deposited by PLD. On the other hand, unexpected elemental interdiffusion led to a massive contamination of the cell. Particularly, nickel from the anode was observed to diffuse throughout the cell toward the cathode contaminating the electrolyte, the cathode materials and even alloying the platinum current collector. Furthermore, strontium was completely depleted from the LSC cathode and new nonidentified phases were formed at the cathode side. Signs of cerium and zirconium solid solution formation were also found at the YSZ/CGO interface. Such effect was not expected at temperature as low as $650{ }^{\circ} \mathrm{C}$ and they can related to formation of hot-spots as well as to chemical reduction of the CGO layer due to the electrolyte failure. LSC cathode completely disaggregates by the degradation test, indicating a crucial instability of these materials even at low temperatures.

\section{Acknowledgements}

The authors thank Dr. Søren Højgaard Jensen and Dr. Sune Veltzé for helpful support in the electrochemical measurements, Dr. Bumsoo Kim for supplying the substrate and Prof. Dr. Nikolaos Bonanos for the technical discussion.

The authors would like to acknowledge the funding from the Science without Borders Program (Projectolo.1249341/201391) from Brazilian National Council for Scientific and Technological Development (CNPq) and the Danish Council for Independent Research (DFF, Project No. DFF 1335-00138) within the ProEco project.

\section{References}

1 2
J. An, Y. B. Kim, J. Park, T. M. Gür and F. B. Prinz, Nano Lett., 2013, 13, 4551-4555.

C.-C. Chao, C.-M. Hsu, Y. Cui and F. B. Prinz, ACS Nano, 2011, 5, 5692-5696.

K. J. Kim, B. H. Park, S. J. Kim, Y. Lee, H. Bae and G. M. Choi, Sci. Rep., 2016, 6, 22443.

E. D. Wachsman and K. T. Lee, Science (80-. )., 2011, 334, 935-939.

Y. Lee, Y. M. Park and G. M. Choi, J. Power Sources, 2014, 249, 79-83.

Y. Lee and G. M. Choi, J. Electroceramics, 2013, 31, 238244.

P.-C. Su and F. B. Prinz, Electrochem. commun., 2012, 16, 77-79.

A. Evans, A. Bieberle-H??tter, J. L. M. Rupp and L. J. Gauckler, J. Power Sources, 2009, 194, 119-129.

S. M. Haile, Acta Mater., 2003, 51, 5981-6000.

E. D. Wachsman, C. A. Marlowe and K. T. Lee, Energy Environ. Sci., 2012, 5, 5498-5509.

S. Sanna, V. Esposito, J. W. Andreasen, J. Hjelm, W. Zhang, T. Kasama, S. B. Simonsen, M. Christensen, S. Linderoth and N. Pryds, Nat. Mater., 2015, 14, 500-504.

M. Z. Khan, R. H. Song, S. B. Lee, J. W. Lee, T. H. Lim and S. J. Park, Int. J. Hydrogen Energy, 2014, 39, 20799-20805.

Z. Li, T. Mori, G. J. Auchterlonie, Y. Guo, J. Zou and J. Drennan, J. Phys. Chem. C, 2011, 115, 6877-6885.

A. Tsoga, A. Gupta, A. Naoumidis and P. Nikolopoulos, Acta Mater., 2000, 48, 4709-4714.

R. W. Balluffi and J. W. Cahn, Acta Metall., 1980, 29, 493500.

R. W. Balluffi and J. M. Bkakely, Thin Solid Films, 1975, 25, 363-392.

S. J. Litzelman, J. L. Hertz, W. Jung and H. L. Tuller, Fuel Cells, 2008, 8, 294-302.

A. Fluri, D. Pergolesi, V. Roddatis, A. Wokaun and T. Lippert, Nat. Commun., 2016, 7, 10692.

C. D. Baertsch, K. F. Jensen, J. L. Hertz, H. L. Tuller, S. T. Vengallatore, S. M. Spearing and M. A. Schmidt, J. Mater. Res., 2004, 19, 2604-2615.

Z. Gao, L. V. Mogni, E. C. Miller, J. G. Railsback and S. A. Barnett, Energy Environ. Sci., 2016, 9, 1602-1644.

V. Esposito, D. W. Ni, S. Sanna, F. Gualandris and N. Pryds, RSC Adv., 2017, 7, 13784-13788.

J. H. Park, S. M. Han, K. J. Yoon, H. Kim, J. Hong, B. K. Kim, J. H. Lee and J. W. Son, J. Power Sources, 2016, 315, 324-330. H. S. Noh, K. J. Yoon, B. K. Kim, H. J. Je, H. W. Lee, J. H. Lee 
and J. W. Son, J. Power Sources, 2014, 249, 125-130. Ramousse and M. Mogensen, Fuel Cells, 2011, 11, 661668. 2009, 701-710.

27 I. Garbayo, V. Esposito, S. Sanna, A. Morata, D. Pla, L. Fonseca, N. Sabaté and A. Tarancón, J. Power Sources, 2014, 248, 1042-1049.

28 H. S. Noh, H. Lee, B. K. Kim, H. W. Lee, J. H. Lee and J. W. Son, J. Power Sources, 2011, 196, 7169-7174. H. S. Noh, K. J. Yoon, B. K. Kim, H. J. Je, H. W. Lee, J. H. Lee and J. W. Son, J. Power Sources, 2014, 247, 105-111.

30 M. Z. Khan, M. T. Mehran, R. H. Song, J. W. Lee, S. B. Lee, T. H. Lim and S. J. Park, Ceram. Int., 2015, 42, 6978-6984. D. H. Myung, J. Hong, K. Yoon, B. K. Kim, H. W. Lee, J. H. Lee and J. W. Son, J. Power Sources, 2012, 206, 91-96. U. P. Muecke, S. Graf, U. Rhyner and L. J. Gauckler, Acta Mater., 2008, 56, 677-687.

33 H. Galinski, T. Ryll, P. Elser, J. L. M. Rupp and L. J. Gauckler, Phys. Rev. B, 2010, 82, 235415.

34 H. S. Noh, J. W. Son, H. Lee, H. II Ji, J. H. Lee and H. W. Lee, J. Eur. Ceram. Soc., 2010, 30, 3415-3423.

35 Z. Ho-Sung Noh, z, y Jong-Sung Park, z Ji-Won Son, w, z Heon Lee, y Jong-Ho Lee, ${ }^{*}, \mathrm{z}$ and Hae-Weon Lee*, J. Am. Ceram. Soc., 2009, 3064, 3059-3064. D. Beckel, A. Bieberle-Hutter, A. Harvey, A. Infortuna, U. P. Muecke, M. Prestat, J. L. M. Rupp and L. J. Gauckler, J. Power Sources, 2007, 173, 325-345. J. H. Joo and G. M. Choi, J. Power Sources, 2008, 182, 589593. R. Raj and S. Ramanathan, J. Power Sources, 2017, 359, 4851.

40 S. Heiroth, T. Lippert, A. Wokaun, M. Döbeli, J. L. M. Rupp, B. Scherrer and L. J. Gauckler, J. Eur. Ceram. Soc., 2010, 30, 489-495.

41 B. A. Infortuna, A. S. Harvey and L. J. Gauckler, Adv. Funct. Mater., 2008, 18, 127-135.

42 D. W. Ni, J. A. Glasscock, A. Pons, W. Zhang, A. Prasad, S. Sanna, N. Pryds and V. Esposito, J. Electrochem. Soc., 2014, 161, 3072-3078.

43 V. Esposito, D. W. Ni, D. Marani, F. Teocoli, T. Sune, D. Z. De Florio and F. C. Fonseca, J. Mater. Chem. A, 2016, 4, 16871-16878.

44 S. De Angelis, P. S. Jorgensen, V. Esposito, E. H. R. Tsai, M. Holler, K. Kreka, E. Abdellahi and J. R. Bowen, J. Power Sources, 2017, 360, 520-527.

45 M. Kubicek, G. M. Rupp, S. Huber, A. Penn, A. K. Opitz, J. Bernardi, M. Stöger-Pollach, H. Hutter and J. Fleig, Phys. Chem. Chem. Phys., 2014, 16, 2715.

46 G. M. Rupp, A. Limbeck, M. Kubicek, A. Penn, M. StogerPollach, G. Friedbacher and J. Fleig, J. Mater. Chem. A, 2014, 2, 7099-7108. 


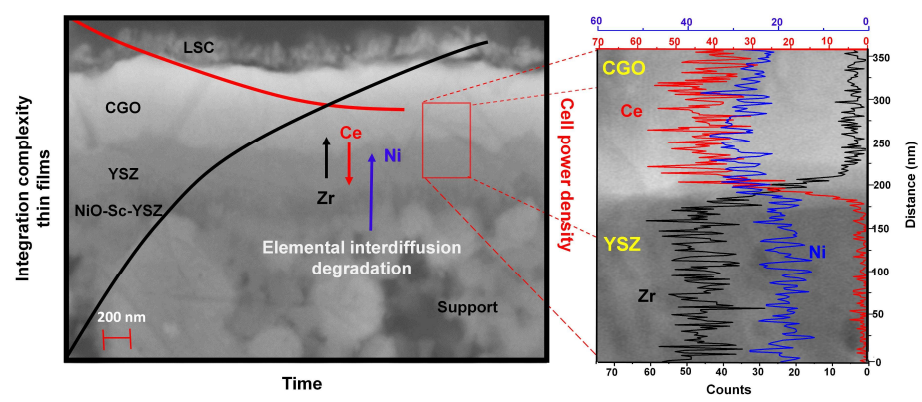

Elemental distribution effects are detected throughout the metal supported TF-SOFC, indicating low energy surface elemental interdiffusion and electromigrative effects. 